\title{
Article \\ Composition of the Wild Rabbit Nest and Its Implication for Domestic Rabbit Breeding
}

\author{
Ágnes Bilkó ${ }^{1}$, Imre Petróczi ${ }^{1}$, Boróka Bárdos ${ }^{2}$, István Nagy ${ }^{3, *(1)}$ and Vilmos Altbacker ${ }^{2}$ (D) \\ 1 Department of Ethology, Eötvös University, 1/C Pázmány P., 1117 Budapest, Hungary; \\ bilkoagnes@gmail.com (Á.B.); petrocziimre@bfnp.hu (I.P.) \\ 2 Kaposvar Campus, Department of Nature Conservation, University of Agricultural and Life Sciences, \\ 40 Guba S., 7400 Kaposvar, Hungary; bardos.boroka@phd.uni-mate.hu (B.B.); \\ altbacker.vilmos@uni-mate.hu (V.A.) \\ 3 Kaposvar Campus, Department of Animal Science, University of Agricultural and Life Sciences, \\ 40 Guba S., 7400 Kaposvar Hungary \\ * Correspondence: nagy.istvan.prof@uni-mate.hu
}

check for updates

Citation: Bilkó, Á.; Petróczi, I.; Bárdos, B.; Nagy, I.; Altbacker, V. Composition of the Wild Rabbit Nest and Its Implication for Domestic Rabbit Breeding. Appl. Sci. 2022, 12 1915. https://doi.org/10.3390/ app12041915

Academic Editor: Franco Mutinelli

Received: 5 January 2022

Accepted: 8 February 2022

Published: 11 February 2022

Publisher's Note: MDPI stays neutral with regard to jurisdictional claims in published maps and institutional affiliations.

Copyright: (C) 2022 by the authors. Licensee MDPI, Basel, Switzerland. This article is an open access article distributed under the terms and conditions of the Creative Commons Attribution (CC BY) license (https:// creativecommons.org/licenses/by/ $4.0 /)$.

\begin{abstract}
Wild European rabbits (Oryctolagus cuniculus) give birth in an underground nursery burrow where the kits are hermetically closed into the nest chamber for several weeks except for the three minutes of daily nursing. Given this confinement, the nest quality seems to be crucial in affecting the kits' survival. The situation is less critical in rabbitries where the domesticated descendants are kept and give birth in separate nest boxes where the temperature and humidity conditions are less extreme and nests consist of fur and wood shavings or straw. However, nesting behaviour of domestic does still reflects several aspects of the ancestors, and providing conditions close to their biological needs is advised. The present study aimed to understand the factors contributing to the nest material choice of rabbits by analysing the composition of wild rabbit nests and testing naive domestic does in controlled laboratory settings for their preferences in constructing their nests. We were able to collect 21 just abandoned nests in their natural habitat and found they contained rabbit fur and hay, of which $85 \%$ was dry grass, mostly long leaves of Calamagrostis sp. Using domesticated rabbit does, we then tested if there is a preference for the features of the wild rabbit nests or whether the above-mentioned finding was either an accidental consequence of grass availability or ageing of the nest material. Two-way choice tests revealed that primiparous domestic does preferred the dry grass over green and long leaves over short grass bunches for nest building. Ageing of the nest material was rather negligible and did not contribute to the high level of dry grass content. We concluded that long dry grass is recommended as it seems to fulfil basic needs of this domesticated animal.
\end{abstract}

Keywords: European rabbit; Oryctolagus cuniculus; nest building; preference

\section{Introduction}

Maternal behaviour of mammals often includes nest building in which they might simply hide the litter from predators or it can be a more elaborate construction providing the young with a balanced microclimate [1]. The quality of the nest can be important for a number of reasons. In general, nests of burrowing small mammals insulate them from fluctuating weather conditions [2-4]. As a result, the nest can affect the magnitude of energy conservation and consequently is considered crucial [5-10] or even critical [11,12] from the aspect of survival or reproduction [13]. Physical features such as the insulation capacity of the nest are of utmost importance where outer conditions are harsh and energetic costs are high [14].

The harsh conditions are also characteristic to litters of the European rabbit (Oryctolagus cuniculus) [15]. Unlike most of the Lagomorphs, the European wild rabbit does construct an underground nursery burrow $[16,17]$. Kindling takes place in the burrow and the doe gives birth to a relatively large litter of 2-6 naked kits with closed eyes [18,19]. These 
underdeveloped animals are only visited once each day $[14,20]$ by the doe. Meanwhile the kits are closed into the nest chamber to reduce predation [21-23] or infanticide [24]. The kits spend much of the day resting [25], and due to their tolerance of high $\mathrm{CO}_{2}$ concentration and low oxygen consumption, they can still breath through aerated sandy soils, the distribution of which limits rabbit range [26,27].

By using an internal clock for anticipating the maternal visits $[25,28]$, the kits uncover from the nest material and are prepared by the time of the next visit to suckle one third of their body mass in just three minutes [14,29] from the extremely rich milk [30]. After nursing, the doe leaves and covers the nest entrance. The kits urinate and burrow back into the grass and fur, becoming dry as they do so [25]. As the contact is already reduced to a minimum, the survival of the offspring is very much dependent on the conditions inside the nest [31]. The doe collects grass and brings it in her mouth to the chamber where a so called "straw nest" [32] is constructed a few days before parturition. On the last night, the mother plucks fur from her belly and incorporates that into the construction [33]. Both the grass and the fur were found to be necessary for the survival of the young $[32,34,35]$ even in laboratory settings, where wood shavings or straw are often provided for practical reasons $[23,36]$. The importance of nesting material has also been demonstrated for wild rabbits in captive condition [37].

The present study aimed to understand the factors contributing to the nest material choice of rabbits by analysing the composition of wild rabbit nests and testing captive domestic animals in controlled laboratory settings for the behavioural processes contributing to making nests in these animals.

\section{Materials and Methods}

\subsection{Animals and Experimental Design}

For the laboratory analysis of nest material choice, experimental subjects were randomly chosen primiparous females of chinchilla bred domestic rabbits, originating from Germany (Standard Chinchilla by Thomae, Biberach) and bred in our laboratory (at Göd, Hungary). The pregnant females, weighing $2.7+0.2 \mathrm{~kg}$, were housed individually in standard wire rabbit cages $(100$ Lenght $\times 50$ Width $\times 45$ Height $\mathrm{cm}$ ) with ad libitum laboratory pelleted rabbit food and water. The cages were equipped with an outer wooden nest-box $(45 \mathrm{~L} \times 40 \mathrm{~W} \times 35 \mathrm{H} \mathrm{cm})$. The entrance was located in the middle of the $45 \mathrm{~cm}$ long side and it was open during the experiment thus the doe could freely visit their kits. Temperature was kept between $18-22^{\circ} \mathrm{C}$. Illumination was also kept constant during the experiments at Light:Dark $=14: 10$ with light on at $0700 \mathrm{~h}$. The animal housing and the studies were carried out in accordance with the European Communities Council Directive of 10/05/2013 $(86 / 609 / \mathrm{EEC})$. The number of animals used in the study was reduced as little as possible (1998./XXVIII. Hungarian law on the protection and welfare of animals). Using a small sample size still enabled us to find large scale differences among the groups.

\subsection{Experiment 1}

For describing the composition of original rabbit nests, we searched for above ground signs of rabbit litters in the open sandy grassland patches of the Bugac Juniper Forest (Kiskunság National Park, Hungary) during the breeding season. We followed their activity until the nest was unoccupied then the nest material was collected into sealable sterile bags and kept at $5{ }^{\circ} \mathrm{C}$ until the analysis. This way the composition of wild rabbits nests $(\mathrm{N}=21)$ could be collected. The plant and fur components were separated and their volume was estimated. Further analysis was restricted to the plant components only. For this purpose, ten subsamples of 25-40 pieces of plants were picked out by forceps from each nest and identified under a NIKON SMZ1270 microscope using $40 \times$ magnifications. For each piece, the species identity and its colour indicating if it was green (fresh) or yellow (dry) were determined under the microscope. The length of the grass pieces was also measured to the nearest $\mathrm{cm}$ using a plastic ruler. These subsample data were then averaged to characterise the composition of the nest. 


\subsection{Experiment 2}

Thirty weeks old randomly chosen primiparous females $(N=7)$ served as subjects and tested on day 28 of pregnancy in a two-way choice test. The cages were equipped with an outer wooden nest box $(45 \mathrm{~L} \times 40 \mathrm{~W} \times 35 \mathrm{H} \mathrm{cm})$ at $9 \mathrm{AM}$. The entrance was located in the middle of the $45 \mathrm{~cm}$ long side and it was open during the experiment thus the doe could freely visit the box. Does were offered two grass tussocks of equal volume, but differing in their dryness, in the two corners opposite to the nest box at 16.00. The predominantly Calamagrostis grass material of both tussocks was collected the same morning from the same place, but one of them was dried out in a drying oven for four hours at $50{ }^{\circ} \mathrm{C}$. The treatment resulted in a yellowish dry grass matching the colour and condition of normal hay. The amount offered was $2 \mathrm{dm}^{3}$ each which was about $200 \mathrm{~g}$ green and $100 \mathrm{~g}$ dry grass. As this is about the volume of a complete nest, any of the two types was sufficient for completing the nest building. The nest material choice tests were run the same afternoon from 16.00 to 17.00. During the one hour of observation, the behaviour of the does was observed from behind a paravan set $2 \mathrm{~m}$ apart. The observer recorded (continuous recording) and the time spent in the following variables: eating, collecting each grass type, or being in the nest box. Behaviour in the nest box was not measured as dim light in the box prevented observation. After the test the percent of time spent was determined for each variable. The resulting nest material were replaced by the same amount of hay, while the composition of the materials collected by the does was analysed in the way described above for wild rabbit nests. Due to the long preparation and analysis phases, only one doe per day was tested.

The resulting nests from this test were also used test if the high percentage of dry material in the wild rabbit nests resulted from ageing due to later recovery of such nests, instead of a preference for such material. Wild rabbit nests were found several weeks apart during the breeding season, thus the storage differences of the wild rabbit nests could be eliminated by using the nests just collected. For this, at the end of the nest composition data collection, the seven nests of known initial composition were put in cotton bags and kept in a refrigerator at $5{ }^{\circ} \mathrm{C}$, which is the average soil temperature (measured at $50 \mathrm{~cm}$ below ground) of the study site in the breeding season (own unpublished data). The composition of these nests was reanalysed once a week for four consecutive weeks, corresponding to the period from parturition until weaning when the original rabbit nests were most probably found.

\subsection{Experiment 3}

Another set of randomly chosen primiparous, thirty-week-old domestic rabbit females $(\mathrm{N}=7)$ were tested on day 28 of pregnancy in a two-way choice test on the preference of the length of nest material. Does were offered two dry grass tussocks of equal volume, but differing in their length, placed in the two corners opposite to the nest box. The material of both tussocks was collected from the same grassland patch, dried out and divided into two tussocks of equal volume $\left(2 \mathrm{dm}^{3}\right)$. One of the tussocks was cut to be long $(30 \mathrm{~cm})$, while the other was short $(10 \mathrm{~cm})$ and presented to the females. During the one hour of observation period from 16.00 to 17.00 the behaviour of the does was monitored the same way described in Experiment 2.

\subsection{Statistical Analyses}

In Experiment 2 and 3 the relative percentage of collecting as well as of eating grass in the two-way choice tests was compared using Wilcoxon matched-pairs signed-ranks tests. The effect of ageing of the nest material in Experiment 2 was analysed by Fisher exact test and by Friedman nonparametric ANOVA for repeated measures followed by Dunn multiple comparison test. IBM SPSS Statistics 27.0 (Student Licence) was used to perform the statistical analyses. 


\section{Results}

\subsection{Experiment 1}

The composition of the wild rabbit nests is summarised in Tables 1 and 2. Each nest contained an outer layer of plant material and an inner cover of rabbit fur in roughly equal volumes. The majority $85 \%( \pm 4 \% \mathrm{SE})$ of plant material was long dry grass, mostly of Calamagrostis epigeios. The remaining green material consisted mostly of bunches of the moss Hypnum cupressiforme, and, being rather variable among the nests, short pieces of different green plants such as Polygonatum officinalis and Colchicum autumnale.

Table 1. Basic elements of the wild rabbit nests $(\mathrm{N}=21)$ from Bugac Juniper Forest, Hungary.

\begin{tabular}{cc}
\hline \multicolumn{2}{c}{ Percent Volume (Standard Error) } \\
\hline Fur & $43(12.2)$ \\
Plant material & $55(14.7)$ \\
Other (eg. sand, litter) & $2(3.8)$ \\
\hline
\end{tabular}

Table 2. The composition of the wild rabbit nests.

\begin{tabular}{cc}
\hline \multicolumn{2}{c}{ Percent Plant Material (Standard Error) } \\
\hline \multicolumn{1}{c}{ Dry } \\
\hline Agropyron & 15.3 \\
Calamagrostis & 67.3 \\
Carex & 13.3 \\
Other & 3.5 \\
\hline Total dry & $84.4(14.5)$ \\
\hline & \\
\hline Colchicum & Green \\
Hypnum c. & 7.5 \\
Polygonatum o. & 3.2 \\
Other & 2.5 \\
\hline Total green & $15.6(14.5)$ \\
\hline
\end{tabular}

\subsection{Experiment 2}

When presented with the grass, the pregnant does immediately started to explore by sniffing both bunches of the unknown grass material. They spent a lot of time hopping in and out of the nest box which behaviour was frequently preceded by digging movements. After a few minutes they started collecting the grass by picking out a few dozen leaves and bringing into the nest box. The females spent more time collecting dry than green grass (Figure 1), which is a significant difference by Wilcoxon matched-pairs signed-ranks test $(\mathrm{W}=26, \mathrm{~N}=7, p<0.05$ ) showing that there is a preference even in the domestic rabbits for collecting dry grass. On the contrary, the animals spent much more time eating the green rather than the dry grass (Wilcoxon test: $\mathrm{W}=21, \mathrm{~N}=7, p<0.05$ ). Additionally, the animals spent $31 \%$ of the test time within the nest box where we sometimes could see them arranging and eating the grass. Although because of the dim light we could not determine which grass type was eaten, analysis of the nest composition after the test suggested there could be a differential grazing inside the nest too. The dry grass content of freshly made nests by primiparous domestic females was $85 \%$, significantly different from chance by Fisher exact test $\left(X^{2}=12.1, p<0.01\right)$, and significantly higher (Wilcoxon matched-pairs signed-ranks test $\mathrm{W}=24, \mathrm{~N}=7, p<0.05$ ) than the $75 \%$ ratio of collection directed to the dry tussock. 


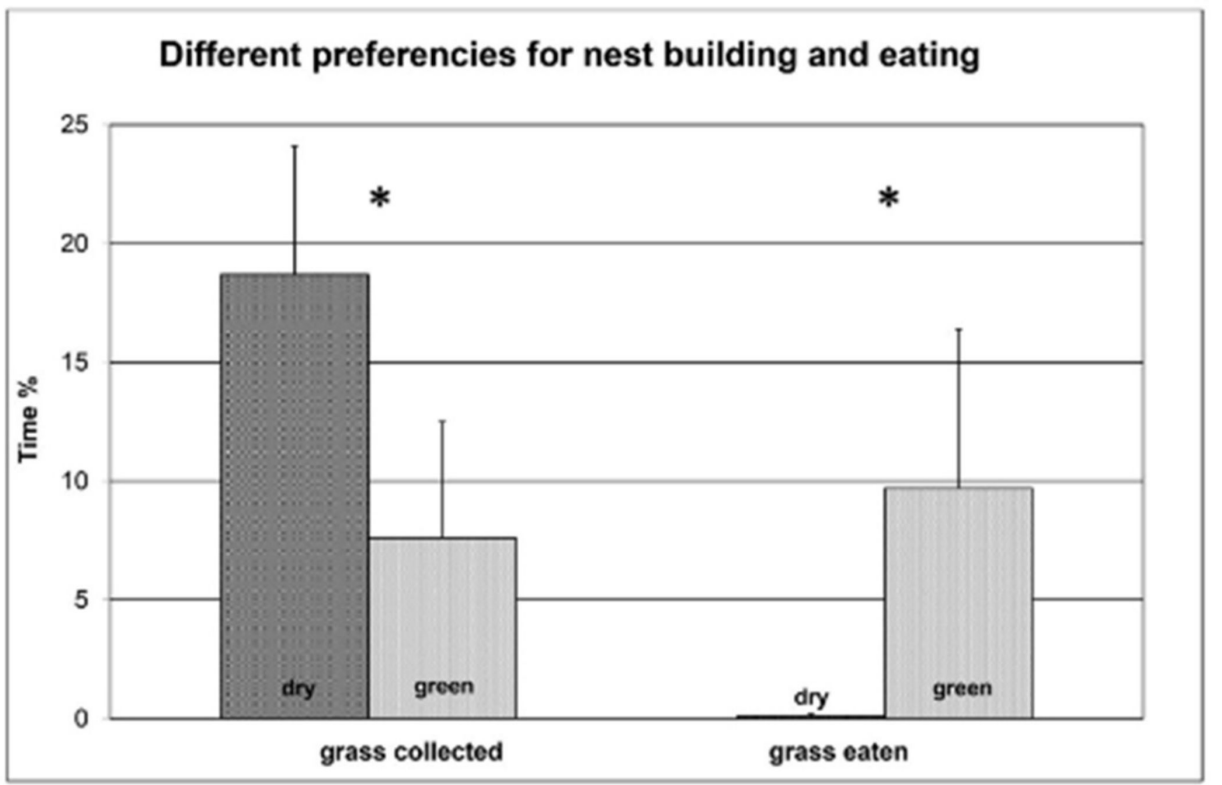

Figure 1. The percentage of time spent collecting or eating from either the green or dry grass by naive primiparous domestic rabbit females $(\mathrm{N}=7)$ during the one-hour observation period. Asterisks indicate significant differences $(p<0.05)$ in Wilcoxon matched-pairs signed-ranks tests.

The effect of ageing on the estimate of grass dryness was tested by repeatedly analysing the composition of stored nests for four weeks (Figure 2). Although the original ratio of $85 \%$ had been gradually increased to $91 \%$ by the end of the 4th week, only the change between the first and the last two weeks was significant by the Dunn test (alpha $=0.05)$ following Friedman nonparametric ANOVA for repeated measures $(\mathrm{Fr}=18.38, \mathrm{~N}=7, p<0.01)$.

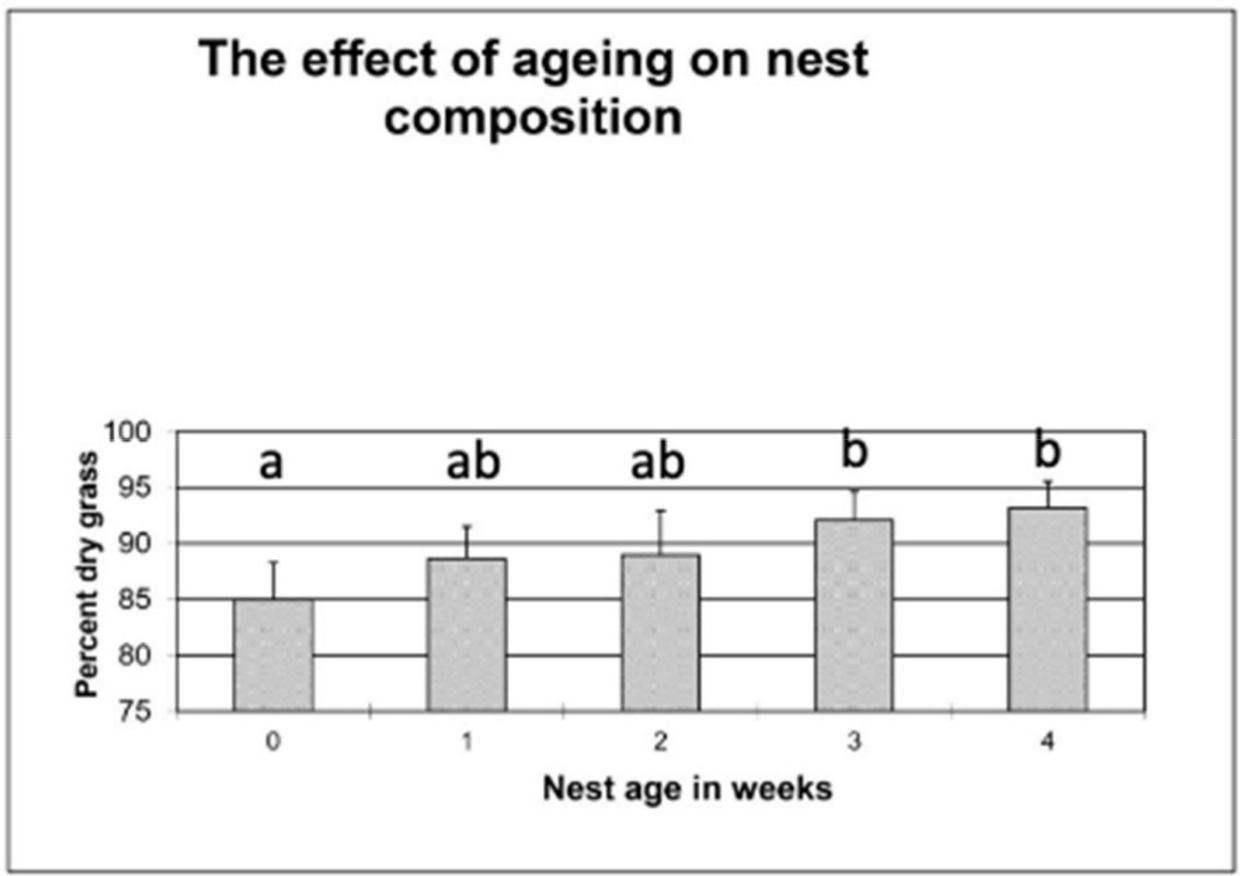

Figure 2. The effect of ageing on the dry matter ratio of nests $(\mathrm{N}=7)$ made by females in Experiment 2. The value for each nest is an average from microscopic observation of 10 subsamples per nest. Different letters above the columns indicate significant differences in post hoc Dunn test (alpha $=0.05$ ) following Friedman nonparametric ANOVA for repeated measures. 


\subsection{Experiment 3}

The does preferred long over short grass when collecting nest material (Wilcoxon matched-pairs signed-ranks test: $W=24, p<0.05$ ). (Figure 3 ). The grass length only marginally affected the eating (Wilcoxon test: $\mathrm{W}=19, p=0.06$ ). The occurrence of eating grass was generally low (3.5\%) similarly to the dry grass eating in the previous experiment. This was probably due to the lack of the green material shown to be preferred for eating. Similar to the previous experiment, the does spent a lot of time $(29 \%$ vs. $31 \%)$ in the nest box.

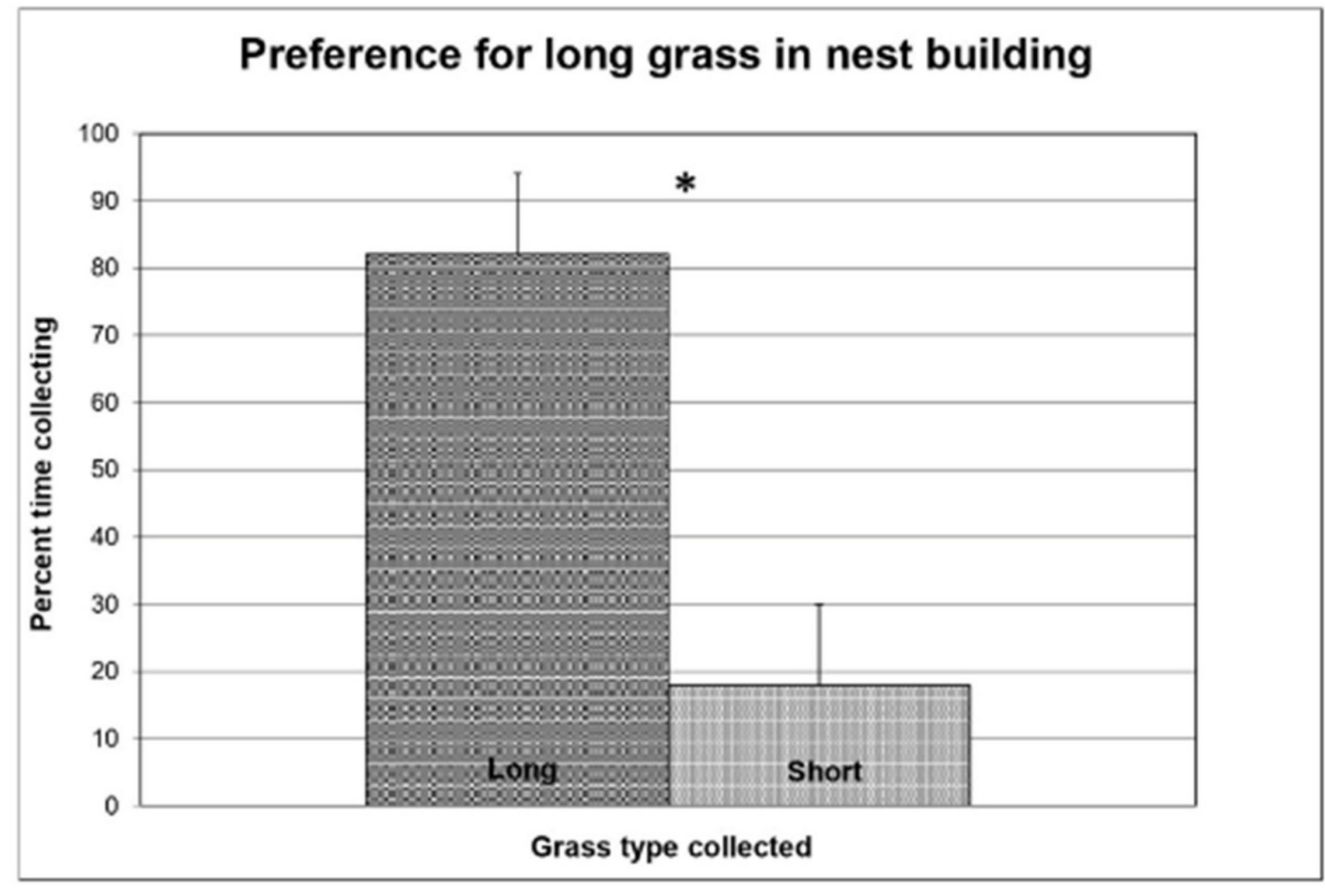

Figure 3. The relative percentage of time spent in collecting from either long $(30 \mathrm{~cm})$ or short $(10 \mathrm{~cm})$ grass by rabbit females $(\mathrm{N}=7)$. Asterisks indicate significant differences $(p<0.05)$ in Wilcoxon matched-pairs signed-ranks tests.

\section{Discussion}

We aimed to study the main features of nest composition of wild rabbits and to test if such features are still preferred in naïve domestic does. The European rabbit is an especially useful mammalian model for studying maternal behaviour [38] as both wild animals and domestic stocks are available, and the domestication of this species has not dramatically changed the features of maternal behaviour [17,39,40]. A well-constructed nest may increase the survival of the offspring and provide long-term benefits to the mother in the wild but is seemingly less important under controlled laboratory settings [36,41]. Remarkable specialization in the physiological mechanisms underlying the above reactions is known for this species [42,43]. Mimicking the ancestral situation in the rearing is still plausible [41] and can improve the welfare status of rabbits [44].

The worldwide distribution of rabbits [45] indicates that it is an adaptable species with high phenotypic plasticity enabling it to cope with the challenges in various local habitats. As the vegetation is completely different in the several continents the rabbit inhabits today, both food and nest material choice should be flexible. Diet composition of these animals should change both locally and seasonally $[46,47]$ to follow food availability. Laboratory data show that the food preferences are fine-tuned by both individual learning and social impacts on diet choice [48] fulfilling the dietary needs of rabbits. Lagomorphs prefer grass species as food wherever these are available [47,49], but grass is also used for nest building, even by domestic females observed in semi-natural habitats [32,50]. The high percent of dry grass found in the field nests could have been explained by the ageing of the material, as 
we have probably found the nests already empty thus being at least 21 days old, when the doe leaves the entrance open and the kits hide outside [18]. Our repeated tests performed mimicking natural conditions indicate that even though there was a significant increase in dry grass scores (see Figure 2), its small dimension suggests that the nests collected in the field should have been predominantly dry at the time of construction.

We have found a remarkably small variation in the composition of both the wild rabbit nests and the laboratory constructed nests suggesting that rabbit nest building is a result of tightly controlled mechanisms [43,51]. While our tests were restricted to the beginning of the nest building, and the plant components are usually collected during several days preceding the parturition [51], we were able to demonstrate that even the initial plant choice indicates clear preferences toward features present in wild rabbit nests. In order to judge the preference in the two-way choice tests, we reduced the time available for nest material collection to one hour as initial observation indicated this period is enough for the does to reduce one bunch of material to minimum. Extending the test period might have resulted in also collecting the inferior material, even though the offered amount of grass was enough to construct a full nest. It would be interesting to follow the process during the several days preceding parturition [51].

The result of Experiment 2 is in accordance with the hypothesis that rabbit does can modify the nest composition by eating out some of the grass disproportionally, as the slight preference to dry grass in the collection phase was found to be significantly enhanced in the final nest composition. Nevertheless, there are other possible explanations of this increase in the dry grass ratio, for example, the time spent collecting is not a reliable measurement of the amount actually collected. The fact that the ratio of dry grass in the nests of inexperienced domestic females closely resembles the ratio found in wild rabbit nests and its very low (4 percent) standard error suggest that domestication had no major impact on this characteristic. Preference for a given dryness can be functional as nests of Mongolian gerbils and hay piles of the pika [52] or ground squirrel nests [53] were also found to be invariant in their ratio of dry material content. Thus, our first experiment supports the idea that both domestic and wild rabbits prefer dry grass for nest building and can influence their nest composition in different phases of the construction.

Based on the Experiment 3, the preference for long grass seems quite functional as the females can more easily (and quickly) collect the long leaves than the same amount of short grass and the long grass can be more easily structured than the short leaves [53-55]. Cottontail rabbit (Sylvilagus floridanus) females were also seen collecting dry long grass and forming an outer grass layer lining the excavated nest cavity [56]. In Blumetto et al. [52] studies, mother rabbits preferred straw to wood chips as a nesting material, and elongated dry material was also preferred in a highly inbred rabbit stock [35]. The functional significance of using dry grass as nest material is not yet fully understood, heat insulation property $[2,13,53,57]$ or / and its high capacity to bind water [53] are likely candidate features enhancing the survival of wild rabbit kits developing in a closed underground chamber for weeks [18]. Even though it might be problematic to incorporate hay as a nest material in rabbit production systems [35] as fungal toxins can induce health issues [58,59], the welfare status can be improved by mimicking natural situations in the rearing environment [60-62]

In summary, by performing laboratory experiments to understand the functional significance of the preference of wild rabbits for dry elongated grass nest material we found that, similarly to their wild ancestors, even unexperienced domestic rabbit females collect dry and long grass preferentially. The even larger proportion of dry grass found in the final nests and occasional observations of the does in the nest chamber suggest a modification of the nest composition after the collection phase by eating some of the green grass (see Experiment 2 and 3), and thus the final composition of the nests was strikingly uniform and similar to the composition of the nests found in the field and made by the wild ancestors. It is important to emphasize that we tested naïve primiparous domestic does without any previous experience with the nest materials, and our observation focussed on the very first efforts in the nest construction, which is not affected by the does learning processes 
in handling or eating grasses Even though there has been some changes in the genetic background in the nest building behaviour due to domestication [63-65], the basic features of choosing the appropriate nest material seem to remain rather conservative. Thus, we recommend providing uncut hay as a nest material in the rabbit production as it seems to fulfil the basic needs of this domesticated animal.

Author Contributions: Conceptualization, V.A. and Á.B.; methodology, V.A.; software, I.N.; validation, B.B., I.N. and V.A.; formal analysis, I.N.; investigation, B.B.; resources, I.P.; data curation, B.B.; writing—original draft preparation, Á.B. and B.B.; writing—review and editing, Á.B. and B.B.; I.N. visualization, B.B.; supervision, V.A.; project administration, B.B.; funding acquisition, B.B. All authors have read and agreed to the published version of the manuscript.

Funding: The work/publication is supported by the EFOP-3.6.3-VEKOP-16-2017-00005 project. The project is co-financed by the European Union and the European Social Fund.

Institutional Review Board Statement: This research was approved by the Committee on the Ethics of Animal Experiments of Eötvös University (permit number: XIV-I-001/532-4/2012). The authors declare that all experiments were performed in accordance with approved guidelines and regulations.

Informed Consent Statement: Not applicable.

Data Availability Statement: The data presented in this study are available on request from the corresponding author.

Conflicts of Interest: There was no conflict of interest among authors.

\section{References}

1. Hansell, M.H. Animal Architecture \& Building Behaviour; Longman: London, UK, 1984.

2. Casey, T.M. Nest insulation: Energy savings to brown lemmings using a winter nest. Oecologia 1981, 50, 199-204. [CrossRef] [PubMed]

3. Gaskill, B.N.; Gordon, C.J.; Pajor, E.A.; Lucas, J.R.; Davis, J.K.; Garner, J.P. Impact of nesting material on mouse body temperature and physiology. Physiol. Behav. 2013, 110, 87-95. [CrossRef] [PubMed]

4. De-Oliveira, M.C.; Lima, S.C.O.; Mesquita, S.A.; Silva, J.A.; Gomes, Y.S.; Attia, Y.A.; Oliveira, H.C. Nesting materials for does: Effect on nest building and performance at first parturition. Rev. Colomb. Cienc. Pecu. 2017, 30, 308-315. [CrossRef]

5. Bethge, P.; Munks, S.; Otley, H.; Nicol, S. Platypus burrow temperatures at a subalpine Tasmanian lake. Proc. Linn. Soc. N. S. W. 2004, 125, 273-276.

6. Geiser, F. Reduction of metabolism during hibernation and daily torpor in mammals and birds-Temperature effect or physiological inhibition? J. Comp. Physiol. B Biochem. Syst. Environ. Physiol. 1988, 158, 25-37. [CrossRef] [PubMed]

7. Houston, A.I.; McNamara, J.M. A theoretical investigation of the fat reserves and mortality levels of small birds in winter. Ornis Scand. 1993, 24, 205-219. [CrossRef]

8. Lovegrove, B.G.; Raman, J.; Perrin, M.R. Heterothermy in elephant shrews, Elephantulus spp. (Macroscelidea): Daily torpor or hibernation? J. Comp. Physiol. B Biochem. Syst. Envrion. Physiol. 2001, 171, 1-10. [CrossRef] [PubMed]

9. McCafferty, D.J.; Moncrieff, J.B.; Taylor, I.R. Winter microclimate of field voles (Microtus agrestis) in SW Scotland. J. Therm. Biol. 2003, 28, 397-401. [CrossRef]

10. Redman, P.; Selman, C.; Speakman, J.R. Male short-tailed field voles (Microtus agrestis) build better insulated nests than females. J. Comp. Physiol. B Biochem. Syst. Environ. Physiol. 1999, 169, 581-587. [CrossRef]

11. Barclay, R.; Lausen, C.L.; Hollis, L. What's hot and what's not: Defining torpor in free-ranging birds and mammals. Can. J. Zool. 2001, 79, 1885-1890. [CrossRef]

12. Pinowski, J.; Haman, A.; Jerzak, L.; Pinowska, B.; Barkowska, M.; Grodzki, A.; Haman, K. The thermal properties of some nests of the Eurasian tree sparrow, Passer montanus. J. Therm. Biol. 2006, 31, 573-581. [CrossRef]

13. Lamprecht, I.; Schmolz, E. Thermal investigations of some bird nests. Thermochim. Acta 2006, 415, 141-148. [CrossRef]

14. Zarrow, M.X.; Farooq, A.; Denenberg, V.H.; Sawin, P.B.; Ross, S. Maternal behaviour in the rabbit: Endocrine control of maternal nest building. J. Reprod. Fertil. 1963, 6, 375-383. [CrossRef] [PubMed]

15. Bautista, A.; Drummond, H.; Martínez-Gómez, M.; Hudson, R. Thermal benefit of sibling presence in the newborn rabbit. Dev. Psychobiol. 2003, 43, 208-215. [CrossRef] [PubMed]

16. Swihart, R.K. Body size, breeding season length, and life history tactics of Lagomorphs. Oikos 1984, 43, 282-290. [CrossRef]

17. Broekhuizen, S.; Mulder, J. Differences and similarities in nursing behaviour of hares and rabbits. Acta Zool. Fenn. 1983, 174, 61-63.

18. Mykytowycz, R. Social behaviour of an experimental colony of wild rabbits, Oryctolagus cuniculus (L.). CS.IRO Wildl. Res. 1958, 3, 7-25. [CrossRef]

19. Henderson, B.A. Regulation of the size of the breeding population of the European rabbit, Oryctolagus cuniculus, by social behaviour. J. Appl. Ecol. 1979, 16, 383-392. [CrossRef] 
20. Lloyd, M.; McCowan, D. Some observations on the breeding burrows of the wild rabbit Oryctolagus cuniculus on the island of Skokholm. J. Zool. 1968, 156, 540-549. [CrossRef]

21. Delibes, M.; Hiraldo, F. The rabbit as prey in the Iberian Mediterranean ecosystem. In Proceedings of the World Lagomorph Conference, Guelph, ON, Canada, 12-16 August 1979; Myers, K., MacInnes, C.D., Eds.; University of Guelph: Guelph, ON, Canada, 1979; pp. 614-622.

22. Jaksic, F.M.; Soriguer, R. Predation upon the European rabbit Oryctolagus cuniculus in Mediterranean habitats of Chile and Spain: A comparative analysis. J. Anim. Ecol. 1981, 50, 269-281. [CrossRef]

23. Rödel, H.G.; Starkloff, A.; Seltmann, M.W.; Prager, G.; von Holst, D. Causes and predictors of nest mortality in a European rabbit population. Mammal. Biol. 2009, 74, 198-209. [CrossRef]

24. Künkele, J. Infanticide in wild rabbits (Oryctolagus cuniculus). J. Mammal. 1991, 73, 317-320. [CrossRef]

25. Hudson, R.; Distel, H. The pattern of behaviour of rabbit pups in the nest. Behaviour 1982, 79, 255-271. [CrossRef]

26. Wood, D.H. The demography of a rabbit population in an arid region of New South Wales Australia. J. Anim. Ecol. 1980, 49, 55-79. [CrossRef]

27. Parer, I.; Libke, J.A. Distribution of rabbit, Oryctolagus cuniculus, warrens in relation to soil type. Aust. Wildl. Res. 1985, 12, 387-405. [CrossRef]

28. Jilge, B. The ontogeny of circadian rhythms in the rabbit. J. Biol. Rhythm. 1993, 8, 247-260. [CrossRef] [PubMed]

29. Hudson, R.; Bilkó, A.; Altbäcker, V. Nursing, weaning and the development of independent feeding in the rabbit. Z. Saeugetierkunde 1996, 61, 39-48.

30. Cowie, A.T. Variations in the yield and composition of the milk during lactation in the rabbit and the galactopoietic effect of the prolactin. J. Endocrinol. 1969, 44, 437-450. [CrossRef] [PubMed]

31. Hamilton, H.H.; Lukefahr, S.D.; McNitt, J.I. Maternal nest quality and its influence on litter survival and weaning performance in commercial rabbits. J. Anim. Sci. 1997, 75, 926-933. [CrossRef]

32. Denenberg, V.H.; Huff, R.L.; Ross, S.; Sawin, P.B.; Zarrow, M.X. Maternal behaviour in the rabbit: The quantification of nest building. Anim. Behav. 1963, 11, 494-499. [CrossRef]

33. Ross, S.; Zarrow, M.X.; Sawin, P.B.; Denenberg, V.H.; Blumenfield, M. Maternal behaviour in the rabbit under seminatural conditions. Anim. Behav. 1963, 11, 283-285. [CrossRef]

34. Verga, M.; Dell'Orto, V.; Carenzi, C. A general review and survey of maternal behaviour in the rabbit. Appl. Anim. Ethol. 1978, 4, 235-252. [CrossRef]

35. Farkas, P.; Szendrő, Z.; Matics, Z.; Radnai, I.; Nagy, I.; Gerencsér, Z. Preference of rabbit does among different nest materials. World Rabbit Sci. 2018, 26, 81-90. [CrossRef]

36. Farkas, T.P.; Szendrő, Z.; Matics, Z.; Mayer, A.; Radnai, I.; Odermatt, M.; Gerencsér, Z. Effect of different nest materials on nest quality and reproduction performance of rabbit does of various breeds. Állattenyésztés Takarmányozás 2016, 65, 35-41.

37. González-Redondo, P. Maternal behaviour in peripartum influences preweaning kit mortality in cage-bred wild rabbits. World Rabbit Sci. 2010, 18, 91-102. [CrossRef]

38. González-Mariscal, G.; Caba, M.; Martínez-Gómez, M.; Bautista, A.; Hudson, R. Mothers and offspring: The rabbit as a model system in the study of mammalian maternal behavior and sibling interactions. Horm. Behav. 2016, 77, 30-41. [CrossRef] [PubMed]

39. Zarrow, M.X.; Sawin, P.B.; Ross, S.; Denenberg, V.; Crary, D.; Wilson, E.D.; Farooq, A. Maternal behaviour in the rabbit: Evidence for an endocrine basis of nest building and additional data on maternal nest building in the Dutch-belted race. J. Reprod. Fertil. 1961, 2, 152-162. [CrossRef]

40. Hafez, E.S. The Behaviour of Domestic Animals; Bailliere \& Tindall: London, UK, 1969.

41. Coureaud, G.; Schaal, B.; Coudert, P.; Hudson, R.; Rideaud, P.; Orgeur, P. Mimicking natural nursing conditions promotes early pup survival in domestic rabbits. Ethology 2000, 106, 207-225. [CrossRef]

42. González-Mariscal, G.; Rosenblatt, J.S. Maternal behavior in rabbits. A historical and multidimensional perspective. Adv. Study Behav. 1996, 25, 333-359.

43. González-Mariscal, G. Neuroendocrinology applied to rabbit breeding. World Rabbit Sci. 2021, 29, 231-238. [CrossRef]

44. Baumans, V. Environmental enrichment for laboratory rodents and rabbits: Requirements of rodents, rabbits and research. Ilar J. 2005, 46, 162-170. [CrossRef] [PubMed]

45. Flux, J.E.C.; Fullagar, P.J. World distribution of the rabbit (Oryctolagus cuniculus). Acta Zool. Fenn. 1983, $174,75-77$.

46. Homolka, M. A comparison of the trophic niches of Lepus europeus and Oryctolagus cuniculus. Folia Zool. 1987, 36, 307-317.

47. Mátrai, K.; Altbäcker, V.; Hahn, I. Seasonal diet of rabbits and their effect on juniper in Bugac Juniper Forest (Hungary). Acta Theriol. 1998, 43, 107-112. [CrossRef]

48. Altbäcker, V.; Hudson, R.; Bilkó, Á. Can rabbit mother's diet influence the pups later food choice? Ethology 1995, 99, 107-116. [CrossRef]

49. Brüll, U. Nahrungsbiologische Studien am Feldhasen in Schleswig-Holstein. Ein Beitrag zu Asungsverbesserung. In Ecology and Management of European Hare Populations; Pielowski, Z., Pucek, Z., Eds.; PWRL: Warsawa, Poland, 1976; pp. $93-103$.

50. Deutsch, J. Nest building behaviour of domestic rabbits under seminatural conditions. Br. J. Anim. Behav. 1957, 5, 53-54. [CrossRef]

51. González-Mariscal, G.; Melo, A.I.; Jiménez, P.; Beyer, C.; Rosenblatt, J.S. Estradiol, progesterone, and prolactin regulate maternal nest-building in rabbits. J. Neuroendocr. 1996, 8, 901-907. [CrossRef] [PubMed] 
52. Millar, J.S.; Zwickel, F.C. Characteristics and ecological significance of haypiles of pikas. Mammalia 1972, 36, 58-68. [CrossRef]

53. Gedeon, C.I.; Markó, G.; Németh, I.; Nyitrai, V.; Altbäcker, V. Nest material selection affects nest insulation quality for the European ground squirrel (Spermophilus citellus). J. Mammal. 2010, 91, 636-641. [CrossRef]

54. Mcgowan, A.; Sharp, S.P.; Hatchwell, B.J. The structure and function of nests of long-tailed tits, Aegithalos caudatus. Funct. Ecol. 2004, 18, 578-583. [CrossRef]

55. Lanteigne, M.; Reebs, S.G. Preference for bedding material in Syrian hamsters. Lab. Anim. 2006, 40, 410-418. [CrossRef] [PubMed]

56. Casteel, D.A. Nest building, parturition and copulation in the Cottontail rabbit. Am. Midl. Nat. 1966, 75, 160-167. [CrossRef]

57. Rosvold, E.M.; Newberry, R.C.; Andersen, I.L. Early mother-young interactions in domestic sows-Nest-building material increases maternal investment. Appl. Anim. Behav. Sci. 2019, 219, 104837. [CrossRef]

58. Ruiz-Castellano, C.; Tomas, G.; Ruiz-Rodriguez, M.; Martin-Galvez, D.; Soler, J.J. Nest material shapes eggs bacterial environment. PLoS ONE 2016, 11, e0148894. [CrossRef]

59. Peles, F.; Sipos, P.; Győri, Z.; Pfliegler, W.P.; Giacometti, F.; Serraino, A.; Pócsi, I. Adverse effects, transformation and channeling of aflatoxins into food raw materials in livestock. Front. Microbial. 2019, 10, 2861. [CrossRef]

60. Schlolaut, W.; Hudson, R.; Rödel, H.G. Impact of rearing management on health in domestic rabbits: A review. World Rabbit Sci. 2013, 21, 145-159. [CrossRef]

61. Trocino, A.; Xiccato, G. Animal welfare in reared rabbits: A review with emphasis on housing systems. World Rabbit Sci. 2006, 14, 77-93. [CrossRef]

62. Verga, M.; Luzi, F.; Petracci, M.; Cavani, C. Welfare aspects in rabbit rearing and transport. Ital. J. Anim. Sci. 2009, 8 (Suppl. 1), 191-204. [CrossRef]

63. Benedek, I.; Altbäcker, V.; Zsolnai, A.; Molnár, T. Exploring the genetic background of the differences in nest-building behavior in European rabbit. Animals 2020, 10, 1579. [CrossRef] [PubMed]

64. Baumann, P.; Oester, H.; Stauffacher, M. Effects of temporary nest box removal on maternal behaviour and pup survival in caged rabbits (Oryctolagus cuniculus). Appl. Anim. Behav. Sci. 2005, 91, 167-178. [CrossRef]

65. Van De Weerd, H.A.; van Loo, P.L.P.; van Zutphen, L.F.; Koolhaas, J.M.; Baumans, V. Preferences for nesting material as environmental enrichment for laboratory mice. Lab. Anim. 1997, 3, 133-143. [CrossRef] [PubMed] 